\title{
A Comparative Study of Locally designed and Imported Alkaline-Surfactant-Polymer Flooding for Enhanced Oil Recovery
}

\author{
${ }^{1}$ Oluwashina Olaniyan Peter, ${ }^{2}$ Prof Mike Onyekonwu \\ ${ }^{1,2}$ Department of Petroleum and Gas Engineering, \\ University of Port Harcourt, Nigeria
}

\begin{abstract}
The production of hydrocarbons from a known reservoir undergo some stages of recovery and about $35-50 \%$ of the hydrocarbon content in the reservoir are able to be recovered from the primary and secondary recovery stage leaving a significant amount of oil trapped or bypassed in the reservoir. During water flooding process, an unstable displacement usually occur in the reservoir as a result of the oil viscosity being higher than water. This implies that the viscosity of the injected fluid needs to be improved upon by adding a polymer or a combination of alkaline- polymer solution to improve sweep efficiency during water flooding process. In this study, an appropriate composition of a locally made Alkaline-Surfactant-Polyme (ASP) slug such as burning of palm bunch, plantain back, archi and a solution of foreign polyanoic cellulose polymer were designed. Several core flooding experiments were carried out in the laboratory, varying the compositions of the slugs to determine the compositions that would perform optimally. Result obtained showed that highest recovery of oil $3.5 \mathrm{ml}$ was observed when the ASP slug composition was $60 \%$ Alkaline and $40 \%$ Polymer. Displacement $64.07 \%$ as against $4.0 \mathrm{ml}$ (78.13\%) by the foreign polymer. The residual oil saturation after flooding with the local alkalinepolymer slug was about $24 \%$.
\end{abstract}

\section{Introduction}

The recovery of hydrocarbon from the reservoir usually undergoes several stage. At the beginning of production, the primary energy comes from the natural drive of the reservoir such as depletion, gas cap, gravity drainage, water, rock compaction and a combination drive which help to push the hydrocarbon towards the perforation. In some cases, the wells may require some form of artificial lift such as gas lift and pumping system. The hydrocarbon fluids are actually trapped in the pore space of the reservoir. Thus, some of the question that are frequently asked are how much oil and gas can be recovered, how much has been produced, how much is remaining in the reservoir and what is the best way to technically and econimically recover the remaining oil? During the primary and other recovery techniques.

Therefore, when the reservoir can no longer perform very well under the primary recovery, a secondary recovery techniques is employed such as water or gas injection to increase hydrocarbon recovery from the reservoir beyond primary recovery. During the injection of water or gas, there are sometimes some bypassed oil left unswept in the reservoir called residual oil saturation that is current a challenge to the oil and gas industry. This requires an enhanced oil recovery technique to increase oil recovery beyond primary or secondary recovery processes.

Enhanced oil recovery is also called tertiary recovery processes. These are further classified under four main groups: miscible gas injection processes, chemical processes, microbial and thermal processes.

A method to improve oil recovery often referred to as tertiary recovery scheme in the form of polymer, surfactant, alkaline or a combination of two or more flooding has proved to be effective in reducing the residual oil saturation in laboratory experiments and field projects through the reduction of interfacial tension and mobility ratio between the oil and water phases. In this study, a combination of Nigeria locally source and foreign alkaline -polymer (AP) solution will be used in conducting the experiment to investigate it efficacy in enhanced oil recovery. From literatures, it has been widely reported that the viscoelasticity of polymer solutions plays an important role in polymer flood operations. These polymer solutions are used in many operations in the petroleum industry, and their viscoelastic effects are generally recognized (Smith, 1970, Achaya, 1986). Protein is a natural polymer, made of amino acid monomers joined together by peptide bonds (Jenkins et al, 1982).

Polymer flooding technique is an enhanced oil recovery method in which polymer solutions are enhanced oil by increasing the viscosity of the injecting fluid to decrease the water/oil mobility ratio. The mobility ratio is lowered as a result of the increase in viscosity and also decrease in aqueous phase permeability. This in turn helps in increasing the volumetric sweep efficiency and lower swept zone oil saturation. The polymer flooding method is considered favorable when the waterflood mobility ratio is high, the reservoir heterogeneity is serious, or a combination of these two happens (Lake Harry W, 1989) 
The most important factors to be considered for polymer flooding are mainly the temperature of the reservoir and the chemical properties of reservoir water. When the reservoir temperature is high or when the salinity content reservoir water is high, the polymer cannot be kept stable and polymer concentration will lose the strength of its viscosity (Farid, 2011).

The purpose of surfactant flooding is to recover the capillary trapped oil after water flooding. When a surfactant solution has been injected, the trapped oil droplets are mobilized due to a reduction in the interfacial tension between oil and water. The coalescence of these drops leads to a local increase in oil saturation and oil bank is generated. The oil bank will start to flow, mobilizing any residual oil in front of the bank. Behind the flowing oil bank, the surfactant will prevent the mobilized oil to be re-trapped. The interfacial tension, the viscosity, and the volume of the surfactant solution behind the oil bank will therefore be of importance for the final residual oil saturation. (Kleppe, Jon et al, 1992).

The major goal of surfactant flooding is to recover the capillary-trapped residual oil after water flooding is exhausted. By the injection of surfactant solution, the residual oil can be pushed or mobilized through a strong lowered interfacial tension (IFT) between oil and water. (Zolotukhin, A.B. et al 2000). The ability to lower the surface tension between aqueous solutions and other phases is one of the most significant aspects of surfactants that raise their applicability in industries. The critical micelle concentration (CMC), one of the main parameters for surfactants, is the concentration at which the surfactant solutions begin to form micelles in large amount (Hoff et al. 2001). Presence of polymer and alkali in a solution of surfactant significantly influences the surface tensions (Nedjhioui et al. 2005; Horváth-Szabó et al. (2002). For evaluating the effect of polymer on the surface properties, surface tension measurements of SDS surfactants have been performed in the presence and absence of polymer.

In the past, different authors, such as Christopher and Middleman (1965); Willhite and Uhl (1986); van Poollen and Jargun (1969); Hirasaki and Pope (1974); Abou-Kassem and Ali (1986); Pruess and Witherspoon (1991), have proposed several models to account for the flow behavior of polymer solutions under different conditions and some other authors have also suggested simple empirical models to account for non-linear relationship between flow rate and the pressure drop for non-Newtonian fluid flow. But these models fall short in accounting for the elastic phenomena manifested by polymer flow in porous media. Carreau model gives a better representation of flow behavior in these shear regimes (Carreau et al. 1979, Bird et al. 1987) while Maxwell came up with a model that accounted for both viscous and elastic components.

\section{Factors Affecting ASP Flooding}

ASP flooding is depended on the concepts expressed below:

- Interfacial tension force between the injected fluid and the residual oil after primary recovery process,

- Capillary number of the displacing fluid

- Mobility ratio between the displacing fluid and the displaced fluid

- Microscopic displacement efficiency,

- Macroscopic sweep efficiency.

Therefore that oil recovery can greatly be improved or enhanced when interfacial tension force (IFT) is lowered and capillary number increased also, reduction in mobility ratio to enhance microscopic displacement efficiency, and macroscopic sweeping efficiency of residual oil trapped in sand-oil-water reservoir system.

\section{Challenges}

The cost of the polymers, the permeability of the reservoir, and the temperature of the reservoir are some of the challenges which deter the application of polymer in enhanced oil recovery scheme. The cost of polymers limits the concentration and slug size of the polymers that can be used to achieve higher oil recovery. Low rock permeability can limit the use of more viscous polymers to improve mobility control, and can cause low injectivity. Polymers are not stable at reservoir temperatures higher than $175 \mathrm{~F}$

It has been observed that most oil fields are in the later production stage and the water production level increases tremendously even as high or more than $80 \%$. As a results water flooding no longer meets the expected needs of oilfield production. Therefore, it is pertinent that a new recovery technique would be considered in place water flooding. This new technique of ASP flooding was developed in the 1980s on the basic concepts of synergy effect of alkali- surfactant and polymer-flooding. This concept considered the benefits of the three flooding methods simultaneously, and oil recovery is significantly improved by reducing interfacial tension (IFT), improving the capillary number, enhancing microscopic displacing efficiency, improving the mobility ratio, and increasing macroscopic sweeping efficiency. Also, this technique is of necessity since oil and water are immiscible and none of these can completely displace the other from a reservoir. 


\section{Objectives of Study}

- To experimentally determine the appropriate composition of locally derived ASP slug (AlkalineSurfactant-Polymer) that would optimally enhance oil recovery from a reservoir.

- Comparative analysis of locally designed and conventionally designed ASP slug.

\section{Materials and Apparatus}

Apparatus or equipment used to carry out this experimental work is as shown in Fig. 3 which consists among others; weighing balance, beaker, measuring cylinder, PH meter, pump, filter paper, sieve or mesh, viscometer, hose, thermometer, sand pack holder and crude oil.

The materials for this research work are locally sourced due to its availability and affordability. This is one of the objectives of this research work, to make use of what we have locally, improve on them and reduce or eliminate the importation of oil field chemicals. These materials are palm bunch ash, plantain bark ash and palm oil (the surfactant source), and archi (the polymer source) and sodium hydroxide as the alkaline source.

\section{Preparation of sand samples}

For the purpose of this of this experiment, a cylindrical sand packed core samples were built. Core samples were designed using unconsolidated sand. The following procedures were used in preparing the core samples (Figure 1).

i. A sample of sand was collected, washed and dried.

ii. A 40/80 sieve plate was used to separate the sand samples into various particle sizes.

iii. Aluminum foils of known weights were improvised into cylindrical shaped body of $(5 \mathrm{~cm}$ and $2 \mathrm{~cm})$ in length and diameter respectively. Wire mesh sizes (200/120) were used to wrap the bottom of the cylindrical shaped body.

iv. Sand samples were poured into the cylindrical shaped aluminum foils and the top also covered/wrapped with a mesh sizes wire (200/120).

v. The cylindrical core samples formed were oven-dried for it to be more compacted.

vi. The weight, length and diameter of each of the core samples were recorded after been dried with oven.

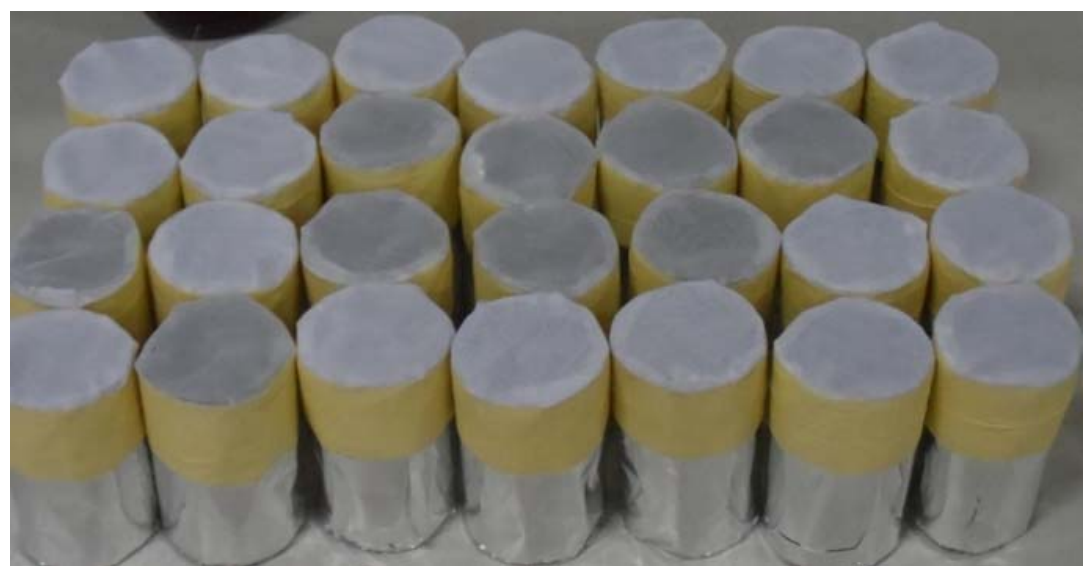

Figure 1: Prepared sand samples

\section{Preparation of Brine}

The concentration of the brine used was 20000ppm and was prepared as follows.

* 20g of common salt ( $\mathrm{Nacl}$ ) was measured using the electronic weighing balance.

* The salt was placed in a beaker and $30 \mathrm{ml}$ of distilled water was added and stirred with magnetic stirrer until the salt dissolved completely to have a uniform solution.

* Introduce the salt solution into $1000 \mathrm{ml}$ measuring cylinder.

* Distilled water was added up to the $1000 \mathrm{ml}$ mark of the cylinder.

\section{Preparation of Alkaline (NaOH)}

The concentration of the $\mathrm{NaOH}$ used was 20000ppm and was prepared as follows.

* $20 \mathrm{~g}$ of $(\mathrm{NaOH})$ pellet was measured using the electronic weighing balance.

* The salt was placed in a beaker and $30 \mathrm{ml}$ of distilled water was added and stirred with magnetic stirrer until the salt dissolved completely to have a uniform solution.

* Introduce the salt solution into $1000 \mathrm{ml}$ measuring cylinder.

* Distilled water was added up to the $1000 \mathrm{ml}$ mark of the cylinder. 


\section{Local Polymer}

The local polymer source is local archi, sourced from a local market. While the foreign polymer is polyanoic cellulose polymer. The concentration of the local archi polymer used was $12500 \mathrm{ppm}$ and prepared as follows:

* The archi was grinded to powdery form.

* 12.5g of the grinded archi was weighed using electronic weighing balance.

* The 12.5g of grinded archi was introduced into a beaker and dissolved with about 30mls of hot distilled water, stirred continually with a magnetic stirrer until the archi dissolved completely, forming a uniform solution.

* The archi solution was introduced into a $1000 \mathrm{ml}$ measuring cylinder and distilled water added up to the $1000 \mathrm{ml}$ mark of the cylinder.

\section{Foreign Polymer}

The foreign polymer used here was polyanoic cellulose polymer. The polymer was also already in powdered form.

* Also same procedure was repeated for the foreign polymer. However, in this case, 6.5g of foreign polymer was used to generate a concentration of 6500ppm.

It was observed that at these concentrations (12500ppm and 6500ppm) for both the local and foreign polymer, same viscosity was attained.

\section{Local Surfactant}

The local surfactant was sourced from burning of palm bunch and plantain back. The ashes generated was poured into water and filtered to get a potassium hydroxide solution. $100 \mathrm{ml}$ of palm oil was then introduced into $300 \mathrm{ml}$ of the potassium hydroxide solution and mixed thoroughly until there was a complete blend of the mixture. This mixture was allowed to sit for four days, solidifying to form a black soap.

* The solid black soap was grinded into powdery form.

* $5 \mathrm{~g}$ of the powdered black soap was weighed using electronic weighing balance.

* The measured quantity of the powdered black soap was introduced into a beaker and dissolved in $50 \mathrm{ml}$ of hot distilled water, stirred continually with a magnetic stirrer until the black soap dissolved completely forming a uniform blended surfactant solution.

* The surfactant solution was introduced into a $1000 \mathrm{ml}$ measuring cylinder and distilled water added up to the $1000 \mathrm{ml}$ mark of the cylinder

\section{Foreign Surfactant}

The foreign Surfactant used was Alkyl aryl Sodium Sulfonate, Anionic. The concentration of the surfactant used was 5000ppm.

\section{Experimental Procedure}

Step 1: Brine solution with measured concentration was formulated in the laboratory and used to perform core flooding experiment until residual oil is obtained.

Step 2: Alkaline Polymer (AP) slug of varying compositions and concentration was prepared in the laboratory using local materials.

Step 3: Enhanced oil recovery was carried out by injecting the formulated AP (local and foreign) slug solution of varying composition.

Step 4: The procedure was repeated using different core samples and different compositions of AP slug (both for the locally designed slug and the foreign slug).

Step 5: Comparative analysis of recovery performance was carried out between a local slug and also foreign slug.

Step 6: Slug compositions with the highest recovery of noted for both AP slugs.

Step 7: Measured quantity of locally designed surfactant (black soap) was added to the slug compositions with highest recovery forming slugs of Alkaline-polymer (AP). Same repeated for the conventional (foreign) AP slug using a measured quantity of conventional surfactant.

Step 8: Recovery performances were noted for both slugs.

\section{Flooding Process}

Step 1: The formation is saturated with $100 \%$ brine

Step 2: The brine in the saturated solution is then flushed out with crude oil until no more is produced.

Step 3: The sand packs were then water flooded until the residual oil saturation is obtained by injecting water at a constant rate until very small quantity of oil is produced. This is done after an initial flooding using the same volume of brine for all samples (with a particular pore volume of the sample). 
Step 4: AP slug solutions at varying compositions were injected into the core to recover residual oil trapped in the core by injecting at a constant rate until or no oil is produced.

Step 5: Calculation of percentage recovery of the residual oil in place by measuring the amount of oil separated from the recovery.

The Figure 2 represents a schematic set up of the flooding process as carried out in the laboratory.

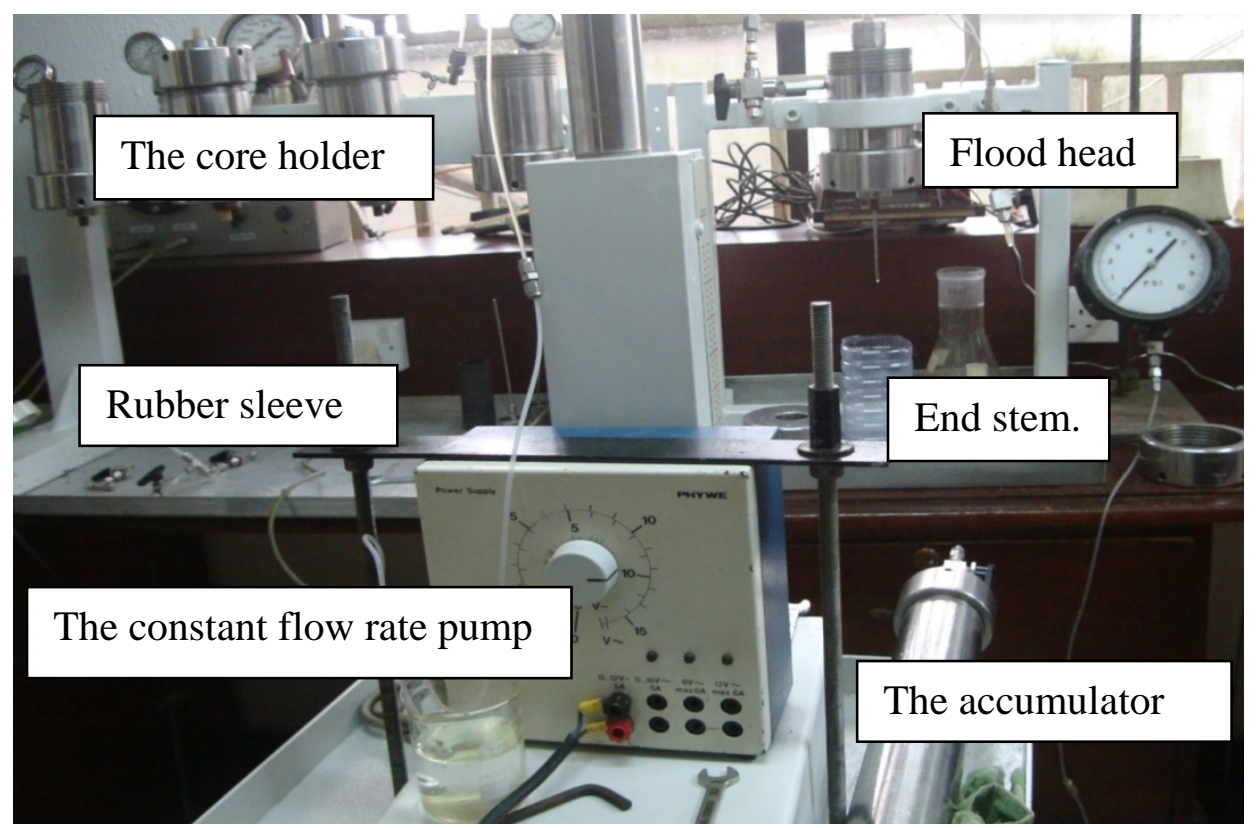

Figure 2: Equipment setup for core flooding experiment

\section{Result and Discussion}

The experimental results for the sand samples used in the flooding with varying compositions of foreign Alkaline, Surfactant and Polymer (ASP) slugs are represented in Table $1 \& 2$ in appendix. We should note that samples A represent sand packs for the foreign ASP slug while samples B represent the local ASP slug.

\section{Observation 1:}

- Approximate volume of oil injected at $60 \%$ pore volume was $13 \mathrm{ml}$ (on average).

- Approximate volume of oil recovered by brine was $8 \mathrm{ml}$ (on average).

- Highest recovery of oil (4ml) was observed when the AP slug composition was $40 \%$ Alkaline and $60 \%$ Polymer. Recovery factor at this point was also observed to be about $78 \%$ and residual oil saturation after flooding was about 5\%. The slug compositions were a combination of sodium Hydroxide and a foreign polymer (See Table 1).

- Highest recovery of oil $(3.5 \mathrm{ml})$ was observed when the AP slug composition was (50\% Alkaline and 50\% Polymer )and (60\% Alkaline and 40\% Polymer) Recovery factor at these point was also observed to be about $63.7 \%$ and $64.07 \%$.Residual oil saturation after flooding was about $24 \%$.The slug compositions were a combination of sodium Hydroxide and a local polymer(See Table 2).

\section{Observation 2:}

The result in Table $1 \& 2$ is an analysis of recovery per volume of injected ASP slug within a time interval. The maximum recovery from water flooding was observed to be about 8ml,it was observed that at a given point, further water flooding do not yield further recovery of the oil. Recovery remained at a marginal despite flooding. At this point it was not economical to continue flooding since recovery remained marginal.

To further recover oil, it was necessary to introduce the foreign ASP slug as the displacing/flooding fluid. Incremental recovery as a result of the ASP slug injection was observed in relation to the oil unrecovered after water flooding. The maximum cumulative recovery achieved by flooding with the foreign ASP slug was about $88.6 \%$ (4.52ml)while that of local ASP slug was about $77 \%(4.2 \mathrm{ml})$. These were amount of the unrecovered oil after water flooding.

\section{Performance and Economic Evaluation}

NPV compares the value of a dollar today to the value of the same dollar in the future, taking inflation and returns into account. If the NPV of a project is positive, it should be accepted. However, if the NPV is negative, the project should probably be rejected because cash flow will also be negative. It is defined by the formula 


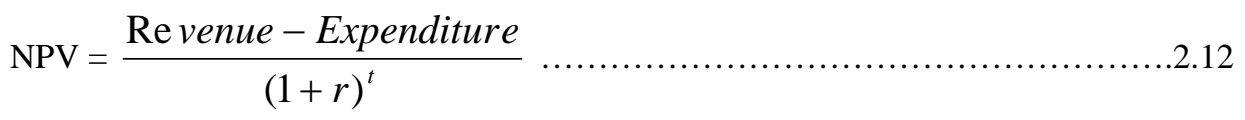

Where $r=$ discount rate

$\mathrm{t}=$ time (years)

\section{Assumptions:}

The following assumptions were made to effectively analyze and compare the NPV of the project for flooding with foreign ASP slug as against local ASP slug.

- $1 \mathrm{ml}$ of crude oil in the laboratory represents $1000 \mathrm{bbl}$ in the field

- $1 \mathrm{ml}$ of other fluids (water, chemicals) represents 1000,000bbl in the field

- \$1(USD) represents N165

- $1 \mathrm{~g}$ in the laboratory represents $1000 \mathrm{~kg}$ in the field

- 2 minutes in the laboratory represents 2 weeks in the field.

- Prevailing price of crude oil as $\$ 93 / \mathrm{bbl}(\mathrm{N} 15,345 / \mathrm{bbl})$

- $\quad$ Foreign Alkaline $\$ 2.5 / \mathrm{Kg}(\mathrm{N} 412.5 / \mathrm{Kg})$

- Foreign Surfactant $\$ 10.5 / \mathrm{Kg}(\mathrm{N} 1732.5 / \mathrm{Kg})$

- Foreign Polymer $\$ 9.0 / \mathrm{Kg}(\mathrm{N} 1485 / \mathrm{Kg})$

- Importation of the foreign alkaline, surfactant and polymer $\$ 2.0 / \mathrm{Kg}$

- Local Surfactant $\$ 3.0 / \mathrm{Kg}(\mathrm{N} 495.0 / \mathrm{Kg})$

- Local Polymer $\$ 2.5 / \mathrm{Kg} \quad(\mathrm{N} 412.5 / \mathrm{Kg})$

Analysis of the foreign slug

Cumulative Volume of ASP slug injected was $58.29 \mathrm{ml}$ which is equivalent to 58,290,000bbls.

\section{Cost of foreign polymer}

Concentration of the Polymer used was 6500ppm (6.5g/1000ml of water) and at a proportion of (60/125)*100\% $=48 \%$

Thus, $48 \%$ of $58,290,000 \mathrm{bbls}$ equals $27,979,200 \mathrm{bbl}$. This would require $181,864 \mathrm{~kg}$ of powdered polymer.

This would eventually cost $\$ 9.0 * 181,864 \mathrm{Kg}=\$ 1,636,776(\mathrm{~N} 270,068,040)$

Importation cost equals $\$ 2.0 * 181,864 \mathrm{Kg}=\$ 363,728(\mathrm{~N} 60,015,120)$

Total cost of the foreign Polymer $=\$ 2,000,504(\mathrm{~N} 330,083,160)$

\section{Cost of foreign Surfactant}

Concentration of the Surfactant used was $5000 \mathrm{ppm}(5.0 \mathrm{~g} / 1000 \mathrm{ml}$ of water) and at a proportion of $(25 / 125) * 100 \%=20 \%$

$20 \%$ of $58,290,000 \mathrm{bbls}$ equals $11,658,000 \mathrm{bbls}$. This would require $58,290 \mathrm{~kg}$ of surfactant.

This would eventually cost $\$ 10.5 * 58,290 \mathrm{~kg}=\$ 612,045(\mathrm{~N} 100,987,425)$

Importation cost equals $\$ 2.0 * 58,290 \mathrm{~kg}=\$ 116,580(\mathrm{~N} 19,235,700)$

Total cost of the foreign Surfactant $=\$ 728,625(\mathrm{~N} 120,223,125)$

\section{Cost of foreign Alkaline}

Concentration of the Alkaline used was 20ppm (20.0g/1000ml of water) and at a proportion of $(40 / 125) * 100 \%=$ $32 \%$

$32 \%$ of $58,290,000 \mathrm{bbls}$ equals $18,652,800 \mathrm{bbls}$. This would require $373,056.00 \mathrm{~kg}$ of $\mathrm{NaOH}$ pellet.

This would eventually cost $\$ 2.5 * 373,056 \mathrm{~kg}=\$ 932,640(\mathrm{~N} 153,885,600)$

Importation cost equals $\$ 2.0 * 373,056 \mathrm{Kg}=\$ 746,112(\mathrm{~N} 123,108,480)$

Total cost of $\mathrm{NaOH}=\$ 1,678,752(\mathrm{~N} 276,994,080)$

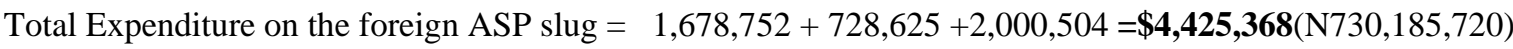

Assume facilities expense and other operations to be $\$ 15,000,000$

Overall expenditure $\$ 19,425,368$

Revenue $=\left(\$ 93^{*}\right.$ Volume of oil Recovered in bbls $)$

Volume Recovered in $\mathrm{ml}(4.527459)=4,527,459 \mathrm{bbl} * \$ 93=\mathbf{\$ 4 2 1 , 0 5 3 , 6 8 7}$

Injection time 22 weeks (154days) 
Therefore time (in years) $=154 / 365=0.4219$ years.

Recall from NPV $=\frac{\text { Revenue }- \text { Expenditure }}{(1+r)^{t}}$

Revenue-Expenditure $=421,053,687-19,425,368=401,628,319$

$(1+0.8)^{t}=(1.8)^{0.4219}=1.28$

$\mathrm{NPV}=401,628,319 / 1.28$

Therefore the NPV when foreign ASP was used $=\$ \mathbf{3 1 3 , 7 7 2 , 1 2 4}$ (excluding overhead cost for the period of 22 weeks and Royalty where the need arises).

\section{Analysis of the local slug}

Applying the same principle as in case of the foreign slug would give a total expenditure of the local slug as (\$521,623.12)

Alsoassuming facilities cost operation cost to be same as in case of foreignslug $\mathbf{( \$ 1 5 , 0 0 0 , 0 0 0 )}$.

Total expenditure $=\$ \mathbf{1 5}, \mathbf{5 2 1}, \mathbf{6 2 3 . 1 2}$

Oil recovery by flooding with local slug was about $4.2 \mathrm{ml}$. This equals $4,200,000 \mathrm{bbls}$.

Revenue from oil recovery $\$ 93 * 4,200,000=\mathbf{3 8 9 , 6 3 7 , 9 1 5}$

Therefore NPV $=(390,600,000-15,521,632.12) / 1.25$

$=\$ 300,062,694$

NPV comparison analysis of the foreign and local slug

NPV of foreign slug $(\$ 313,772,124)$

NPV of local slug $(\$ 300,062,694)$

\section{Conclusion}

From the experimental results obtained, applications of both the foreign and local ASP were very effective. Though flooding cost was intensive, the ASP flooding project was worthwhile. This could be observed from the incremental oil Recovery after water flooding failed to yield further recovery.

* Result obtained shows clearly that the local slugs performed competitively well against the foreign slug which justifies the aim of study is to compare both the foreign and the local slugs in terms of recovery performance and economic value.

4 A recovery of $4.189 \mathrm{ml}$ was obtained by the local slug as against $4.59 \mathrm{ml}$ by the foreign polymer. Also from the NPV analysis of both cases the local slug competed favorably. With further research work, the local chemicals could yield improved performance as we gradually eliminate the importation of oil field chemicals and also reducing cost in Oil and gas operations.

\section{Recommendations}

\& Nigeria as a nation is endowed with adequate resources which could be profitable as Oil field Chemical. More research should be geared towards maximizing these potentials which would also go a long way to eliminate cost of importation of oil field chemicals. This would also go a long way to boost local participation in the Oil and gas sphere.

* ASP flooding can be applicable in oil fields where water flooding could not recover further fluids.

\section{Reference}

[1] Abou-Kassem, J. H., and Farouq Ali, S. M. (1986): "Flow of Non-Newtonian Fluid in Porous Media”. SPE 15954, Eastern Regional Meeting, Columbus, Ohio, USA, 12-14 November

[2] Acharya, A. (1986): "Particle Transport in Viscous and Viscoelastic Fracturing Fluid," SPEPE 369-82.

[3] Bird, R. B., Stewart, W. E. and Lightfoot, E. N. (1960): "Transport Phenomena”. Wiley, New York

[4] Christopher, R.H., and Middleman, S. (1965): "Power-Law Flow through a Packed Tube”. Ind. Eng. Chem. Fund. 4(4): 422-426

[5] Farid, Abadli.(2011) “Investigation of Polymer Flooding for Improved oil Recovery”, Semester Project, NTNU, 2011.

[6] Green, D.W and Willhite, G.P. (1998): "Enhanced Oil Recovery”.-SPE Text-book Series vol 6, Society of Petroleum Engineers, Richardson Texas.

[7] Hirasaki, G. J., and Pope, G. A. (1974): “Analysis of Factors Influencing Mobility and Adsorption in Flow of Polymer Solution through Porous Media”. SPE Journal, 14(4): 337-346.

[8] Hirasaki, G.J., Miller, C.A., Puerto: (2008): “Recent Advances in Surfactant EOR, Society of Petroleum Engineers,” Rice University

[9] Horváth-Szabó G, Czarnecki J, Masliyah JH (2002): "Sandwich structures at oil-water interfaces under alkaline conditions”. J Colloid Interface Sci 253:427-434

[10] Kleppe, J and Skjaeveland, S. M. (1992): "SPOR Monograph-Recent Advances in Improved Oil Recovery Methods for North Sea Sandstone Reservoirs” NPD Stavanger.

[11] Lake, L W. (1989) Enhanced Oil Recovery, University of Texas at Austin.

[12] Nedjhioui M, Moulai-Mostefa N MorsliABensmaili A (2005) Combiner effect of polymer/surfactant/oil/alkali on physical and chemical properties. Desalination 185: 543-550 
[13] Pruess, W. K., and Witherspoon, P. A. (1991): "Displacement of a Newtonian Fluid by a Non-Newtonian Fluid in a Porous Medium”. Transport in Porous Medium, 6(2): 115-142.

[14] Salehi M, Johnson, S.J. \& Liang, J.-T (2010): Journal of Surfactant and Detergents, 13 (3), 243-246, 2010

[15] Samanta A, Ojha K, Mandal A. (2011) The characterization of natural surfactant and polymer and their use in enhanced recovery of oil. Petrol SciTechnol 29:765-777.

[16] Sheng, James J.: (2011) “Modern Chemical Enhanced Oil Recovery (Theory and Practice)” Elsevier Inc, USA.

[17] Shupe R. D (1981) Chemical stability of polyacrylamide polymers. J Petrol Technol 33:1513-1529.

[18] Smith, F. W. (1970): "The Behavior of Partially Hydrolyzed Polyacrylamide Solutions in Porous Media," JPT 148-56.

[19] Suksamranchit, S, Sirivat A (2007) Influence of ionic strength on complex formation between poly (ethylene oxide) and cationic surfactant and turbulent wall shear stress in aqueous solution. ChemEng J 128:11

[20] Van Poollen, H. K., and Jargon, J. R. (1969): "Steady State and Unsteady State Flow of non-Newtonian Fluids through Porous Media". SPE Journal, 9(1): 80-88

[21] Willhite, G. P., and Uhl, J. T. (1986): "Correlation of the Mobility of Biopolymer with Polymer Concentration and Rock Properties in Sandstone”. Polymeric Science and Engineering. 55: 577-581.

[22] Zolotukhin, A. B. and Ursin, Jann-Rune,: (2000)“Introduction to Petroleum Reservoir Engineering,” Norway (2000). 
Table 1: Experiment result of flooding with Foreign ASP slug

\begin{tabular}{|c|c|c|c|c|c|c|c|c|c|c|c|c|}
\hline samples & $\begin{array}{l}\text { Alkaline } \\
\text { (NaoH) } \\
\text { (Composition } \\
\text { by \%) }\end{array}$ & $\begin{array}{l}\text { Polymer } \\
\text { (Composition } \\
\text { by \%) }\end{array}$ & $\begin{array}{l}\text { VOLUME } \\
\text { OF OIL } \\
\text { INJECTED } \\
(60 \% \quad \text { OF } \\
\text { PORE } \\
\text { VOLUME) }\end{array}$ & $\begin{array}{l}\text { VOLUME OIL } \\
\text { RECOVERED } \\
\text { BY } \\
\text { (ml) }\end{array}$ & $\begin{array}{l}\text { VOLUME OIL } \\
\text { RECOVERED } \\
\text { BY NAOH \& } \\
\text { FORIEGN } \\
\text { POLYMER. } \\
\text { (ml) }\end{array}$ & $\begin{array}{l}\text { Water } \\
\text { Saturation. } \\
\text { (sw) (\%) }\end{array}$ & $\begin{array}{l}\text { Recovery } \\
\text { Factor. } \\
\text { (\%) by } \\
\text { brine }\end{array}$ & $\begin{array}{l}\text { Residual oil } \\
\text { Saturation. } \\
\text { (\%) after } \\
\text { Brine } \\
\text { flooding }\end{array}$ & $\begin{array}{l}\text { Recovery } \\
\text { Factor. (\%) } \\
\text { by (Naoh \& } \\
\text { Foriegn } \\
\text { Polymer) }\end{array}$ & $\begin{array}{l}\text { Residual oil } \\
\text { Saturation. } \\
\text { (\%) after } \\
\text { (Akaline \& } \\
\text { Polymer) } \\
\text { flooding }\end{array}$ & $\begin{array}{l}\text { Pore } \\
\text { volume } \\
\text { injection } \\
\text { of ASP } \\
\text { slug at } \\
\text { 2mins } \\
\text { time } \\
\text { interval } \\
\text { (ml) } \\
\end{array}$ & $\begin{array}{l}\text { Recovery } \\
\text { after } \\
\text { flooding } \\
\text { with ASP } \\
\text { flug at } \\
\text { various } \\
\text { injection } \\
\text { volume } \\
\text { (\%) }\end{array}$ \\
\hline A1 & 0 & 0 & 13.38589 & 7.8 & 0.0 & 8.923925 & 58.27033 & 25.03780 & 0.00000 & 25.03780 & 25.00 & 37.50 \\
\hline A2 & 0 & 100 & 13.03000 & 8.0 & 3.0 & 8.686668 & 61.39677 & 23.16194 & 59.64213 & 9.34767 & 27.00 & 41.25 \\
\hline A3 & 10 & 90 & 13.12988 & 8.0 & 2.8 & 8.753253 & 60.92973 & 23.44216 & 54.58218 & 10.64692 & 29.16 & 45.38 \\
\hline A4 & 20 & 80 & 13.23320 & 8.0 & 3.0 & 8.822134 & 60.45401 & 23.72760 & 57.32629 & 10.12544 & 31.49 & 49.91 \\
\hline A5 & 30 & 70 & 13.24927 & 7.6 & 3.8 & 8.832849 & 57.36164 & 25.58302 & 67.26529 & 8.37453 & 34.01 & 54.90 \\
\hline A6 & 40 & 60 & 13.11955 & 8.0 & 4.0 & 8.746365 & 60.97772 & 23.41337 & 78.13191 & 5.12006 & 36.73 & 60.39 \\
\hline A7 & 50 & 50 & 13.28429 & 7.9 & 3.5 & 8.856192 & 59.46875 & 24.31875 & 65.00396 & 8.51060 & 39.67 & 66.43 \\
\hline A8 & 60 & 40 & 13.08051 & 7.8 & 3.2 & 8.720343 & 59.63068 & 24.22159 & 60.60016 & 9.54327 & 42.85 & 73.08 \\
\hline A9 & 70 & 30 & 13.54144 & 8.0 & 3.0 & 9.027629 & 59.07790 & 24.55326 & 54.13752 & 11.26074 & 46.27 & 80.38 \\
\hline A10 & 80 & 20 & 13.21655 & 8.0 & 2.8 & 8.811036 & 60.53015 & 23.68191 & 53.67528 & 10.97058 & 49.98 & 88.42 \\
\hline A11 & 90 & 10 & 13.41516 & 7.9 & 2.6 & 8.943441 & 58.88859 & 24.66684 & 47.14277 & 13.03821 & 53.97 & 88.51 \\
\hline A12 & 100 & 0 & 13.25731 & 8.0 & 2.4 & 8.838206 & 60.34407 & 23.79356 & 45.65073 & 12.93162 & 58.29 & 88.60 \\
\hline
\end{tabular}


Table 2: Experiment result of flooding with Local ASP slug

\begin{tabular}{|c|c|c|c|c|c|c|c|c|c|c|c|c|}
\hline Samples & $\begin{array}{l}\text { Alkaline } \\
\text { (NaoH) (\% } \\
\text { Composition) }\end{array}$ & $\begin{array}{l}\text { Polymer (\% } \\
\text { Composition) }\end{array}$ & $\begin{array}{l}\text { VOLUME } \\
\text { OF OIL } \\
\text { INJECTED } \\
(60 \% \text { OF } \\
\text { PORE } \\
\text { VOLUME) }\end{array}$ & $\begin{array}{l}\text { VOLUME OF } \\
\text { OIL } \\
\text { RECOVERED } \\
\text { BY BRINE. } \\
\text { (ml) }\end{array}$ & $\begin{array}{l}\text { VOLUME OF } \\
\text { OIL } \\
\text { RECOVERED } \\
\text { BY NAOH \& } \\
\text { FORIEGN } \\
\text { POLYMER. } \\
\text { (ml) }\end{array}$ & $\begin{array}{l}\text { Recovery } \\
\text { Factor.(\%) } \\
\text { using } \\
\text { brine }\end{array}$ & $\begin{array}{l}\text { Recovery } \\
\text { Factor. } \\
\text { (\%) using } \\
\text { (Naoh \& } \\
\text { local } \\
\text { Polymer) }\end{array}$ & $\begin{array}{l}\text { Residual oil } \\
\text { Saturation. } \\
(\%) \text { after } \\
\text { Brine } \\
\text { flooding }\end{array}$ & $\begin{array}{l}\text { Residual oil } \\
\text { Saturation. } \\
\text { (\%) after } \\
\text { (Akaline \& } \\
\text { Polymer) } \\
\text { flooding }\end{array}$ & $\begin{array}{l}\text { Pore } \\
\text { volume } \\
\text { injection of } \\
\text { ASP slug at } \\
\text { 2mins time } \\
\text { interval } \\
\text { (ml) }\end{array}$ & $\begin{array}{l}\text { Recovery } \\
\text { after } \\
\text { flooding } \\
\text { with ASP } \\
\text { flug at } \\
\text { various } \\
\text { injection } \\
\text { volume } \\
(\%)\end{array}$ & $\begin{array}{l}\text { Volume } \\
\text { of oil } \\
\text { recovered } \\
\text { by } \\
\text { flooding } \\
\text { with ASP } \\
\text { slug (ml) }\end{array}$ \\
\hline B1 & 0 & 100 & 13.14366 & 8.00 & 2.00 & 60.8659 & 38.8829 & 23.4805 & 14.3506 & 29.50 & 32.55 & 1.77723 \\
\hline B2 & 10 & 90 & 13.03517 & 8.50 & 2.20 & 65.2082 & 48.5098 & 20.8751 & 10.7486 & 31.86 & 35.81 & 1.954953 \\
\hline B3 & 20 & 80 & 13.52365 & 7.80 & 2.50 & 57.6767 & 43.6784 & 25.3940 & 14.3023 & 34.41 & 39.39 & 2.150448 \\
\hline B4 & 30 & 70 & 13.11553 & 8.00 & 3.00 & 60.9964 & 58.6450 & 23.4022 & 9.6780 & 37.16 & 43.32 & 2.365493 \\
\hline B5 & 40 & 60 & 13.42377 & 8.00 & 3.00 & 59.5958 & 55.3121 & 24.2425 & 10.8335 & 40.13 & 47.22 & 2.578388 \\
\hline B6 & 50 & 50 & 13.49323 & 8.00 & 3.50 & 59.2890 & 63.7148 & 24.4266 & 8.8632 & 43.35 & 51.47 & 2.810442 \\
\hline B7 & 60 & 40 & 13.46223 & 8.00 & 3.50 & 59.4255 & 64.0764 & 24.3447 & 8.7455 & 46.81 & 56.11 & 3.063382 \\
\hline B8 & 70 & 30 & 13.50184 & 8.00 & 2.50 & 59.2512 & 45.4394 & 24.4493 & 13.3397 & 50.56 & 62.28 & 3.400354 \\
\hline B9 & 80 & 20 & 13.58335 & 8.00 & 2.00 & 58.8957 & 35.8208 & 24.6626 & 15.8283 & 54.60 & 68.51 & 3.74039 \\
\hline B10 & 90 & 10 & 13.6815 & 8.20 & 2.00 & 59.9349 & 36.4864 & 24.0390 & 15.2681 & 58.97 & 76.73 & 4.189236 \\
\hline B11 & 100 & 0 & 13.19819 & 8.00 & 1.80 & 60.6144 & 34.6275 & 23.6314 & 15.4484 & 63.69 & 76.73 & 4.189655 \\
\hline
\end{tabular}

